\title{
USING TEACHING PROFICIENCY THROUGH READING AND STORYTELLING (TPRS) IN TEACHING ENGLISH FOR YOUNG LEARNERS
}

\author{
Arini Octaviani ${ }^{1}$, Vega Hesmatantya ${ }^{2}$ \\ ${ }^{1}$ Junior Activity Centre School Surabaya, Indonesia, arinioctaviani@gmail.com, \\ ${ }^{2}$ University of Muhammadiyah Surabaya, Indonesia, vegahesmatantya @ fkip.um-surabaya.ac.id
}

\begin{abstract}
This study was conducted in order to find out how to improve students' skills in retelling at kindergarten students of JAC School Surabaya. It described the implementation of Using Teaching Proficiency through Reading and Storytelling (TPRS) in teaching learning process and reported students' retelling story ability. This research used Classroom Action Research (CAR) which is conducted to solve the students' during story telling time and students' ability in retelling story. The study uses Burns theory. This Classroom Action Research has four steps in one cycle. Those are planning, acting, observing, and reflecting. The writer used a descriptive qualitative design to gain the information concerning process of TPRS method. There are three steps of TPRS teaching method. Those are Established the Meaning, Tell a class story and Read. There was an activity called circling in tell a class story step According to the data, the students made an improvement of retelling story use their own language from the first to the second cycle. The average of students score in retelling story rubric of the first cycle was 2 as described as fair category. While the second cycle average of retelling story rubric was 4 and categorized as excellent. The data was the result of direct observation. The analysis was done by describing the implementation of using TPRS in learning process in the classroom.
\end{abstract}

Keywords: TPRS, CAR, Young Learners.

English is foreign language that learned by Indonesian students at School. One of the ways to teach English for young learner is by using storytelling. The children love listening to the stories and retelling. The methods used to teach English for young learners is usually using flashcard (picture), sing an English song, storytelling and etc. Storytelling can be a tool for teachers to teach English for young Learners. Indonesia has printed many kinds of storybook for children. Story book in English version can be a media to teach English for young learner because it uses a simple language and interesting pictures. It helps student to study language in fun ways.

The Teaching Proficiency through Reading and Storytelling (TPRS) method invented by Blaine Ray. A lot of people know about Total Physical Response by James Asher. TPR by James Asher is the predecessor of TPR Storytelling by Blaine Ray. The differences is TPR by Asher based on the coordination of language and physical movement of the students (Caroline Linse, David Nunan 2005), While TPRS by Blaine Ray is an input-based approach to teaching language that focuses on the systematic instruction of vocabulary in a highly comprehensible, personalized and contextualized manner (Carol Gaab, 2011).

Compared to storybook where teacher only need the text, TPRS comes with several benefits in teaching English for Young Learners. It is a language teaching method which also can be used to help students to improve their vocabulary and develop real fluency based on Lichtman (2013). It encourages active participation during the lesson and enhanced listening skills. It is acquired comprehensible input (listening and understanding) as a tool to teach language for children. According to hedstrom (2012), TPRS is also can be adapted for the upper levels of learners and curriculum.

The problem was because of the teaching English with TPRS method had never been used in most of pre-school level. In JAC School which the writer conducted the study also had story telling time in the class. The teacher told a story and the student listen. The story was written and told in English but it was just story reading. The student didn't involve in the story. The writer tries to find out the students improvement in 
English using TPRS in teaching English for young learners also teacher presentation using TPRS. The writer chose young learner to study with TPR Storytelling method because it was easier for young learner to receive the lesson that teacher give especially when they are learning foreign language.

In TPRS, Students and teachers spend class time speaking in the target language about interesting, comprehensible stories (Lichtman \& Krashen, 2013). In the story, teacher gives personal question and answer. So, the students will get involved in the story. Stories are the heart of the method, but the story is only a part of it. It is a good method especially for the teacher who taught Kindergarten, so they can teach English as a foreign language for their students in a fun and easy way. There were three steps to do TPRS activities. They are:

Step \#1: Establish Meaning Pick useful grammatical structures (usually three) and establish meaning with written translation and TPR gestures for a few minutes. Students are showing they understand with gestures. Begin to get it deeper into students' memories with novel commands, very short "ministories" and comprehension checks. Once students have the vocabulary and structures in short term memory, begin asking personalized questions (PQA) and then play with their answers.

Step \#2: Tell a Class Story, The class story is uniquely built by asking questions using the target structures. It is sometimes described as "asking" the story. The goal of the story is to provide compelling comprehensible input. The story is short, simple and interesting. It contextualizes the target structures and provides repetitions. It is told slowly with constant comprehension checks and ideas from the students.

Step \#3: Read Reading is based on the material in the two previous steps. It reinforces the content in a different format. Reading can be at a slightly higher level than the spoken language in the classroom because students can comprehend more vocabulary and more grammar forms since the input is more under the reader's control.

This study will explain the TPRS process in the class. The writer mentioned the students as young learners in this study. The observation study will be held at Junior Activity Centre (JAC) School in Kindergarten level. The school use English to deliver the lesson and daily communication. The writer will observe when the teacher conduct the TPRS method in the class and the students respond in TPRS.

\section{RESEARCH METHODOLOGY}

The writer used Classroom Action Research as the design to overcome the problem. According to Burns (2010) she explained that Action research involves taking a self-reflective, critical, and systematic approach to exploring your own teaching contexts. In Action Research, a teacher becomes an 'investigator' or 'explorer' of their personal teaching context, while at the same time being one of the participants in it. This research design is suitable for this study. The researcher observed the teacher in the classroom who did Teaching Proficiency through Reading and Storytelling method in Young Learner classroom. After the teacher did storytelling, the teacher asked students to retell the story. The writer wanted to know the students ability to tell the story after they study with TPRS. The writer adapted Brown (2001) Oral Proficiency scoring.

\begin{tabular}{|c|c|c|c|c|}
\hline & $\begin{array}{l}\text { Excellent } \\
4 \text { points }\end{array}$ & $\begin{array}{l}\text { Good } \\
3 \text { points }\end{array}$ & $\begin{array}{l}\text { Fair } \\
2 \text { points }\end{array}$ & $\begin{array}{l}\text { Needs to improve } \\
1 \text { points }\end{array}$ \\
\hline Grammar & $\begin{array}{l}\text { Able to use the } \\
\text { language } \\
\text { accurately on } \\
\text { all levels } \\
\text { normally }\end{array}$ & $\begin{array}{l}\text { Control of } \\
\text { grammar is } \\
\text { good. Able to } \\
\text { speak the } \\
\text { language with } \\
\text { sufficient }\end{array}$ & $\begin{array}{l}\text { Can usually } \\
\text { handle } \\
\text { elementary } \\
\text { constructions } \\
\text { quite accurately }\end{array}$ & $\begin{array}{l}\text { Errors in grammar } \\
\text { are frequent, but } \\
\text { speaker can be } \\
\text { understood by a } \\
\text { native speaker used } \\
\text { to dealing with }\end{array}$ \\
\hline
\end{tabular}




\begin{tabular}{|c|c|c|c|c|}
\hline & $\begin{array}{l}\text { pertinent to } \\
\text { professional } \\
\text { needs. Errors in } \\
\text { grammar are } \\
\text { quite rare }\end{array}$ & $\begin{array}{l}\text { structural } \\
\text { accuracy to } \\
\text { participate } \\
\text { effectively in } \\
\text { most formal and } \\
\text { informal } \\
\text { conversations on } \\
\text { practical, social, } \\
\text { and professional } \\
\text { topics }\end{array}$ & $\begin{array}{l}\text { but does not } \\
\text { have thorough } \\
\text { or confident } \\
\text { control of the } \\
\text { grammar }\end{array}$ & $\begin{array}{l}\text { foreigners } \\
\text { attempting to speak } \\
\text { his/her language }\end{array}$ \\
\hline Vocabulary & $\begin{array}{l}\text { Can understand } \\
\text { and participate in } \\
\text { any conversation } \\
\text { within the range } \\
\text { of his experience } \\
\text { with a high } \\
\text { degree of } \\
\text { precision }\end{array}$ & $\begin{array}{l}\text { Able to speak the } \\
\text { language with } \\
\text { sufficient } \\
\text { vocabulary to } \\
\text { participate } \\
\text { effectively in } \\
\text { most formal and } \\
\text { informal } \\
\text { conversations on } \\
\text { practical, social, } \\
\text { and professional } \\
\text { topics. } \\
\text { Vocabulary is } \\
\text { broad enough } \\
\text { that he rarely has } \\
\text { to grope for a } \\
\text { word }\end{array}$ & $\begin{array}{l}\text { Has speaking } \\
\text { vocabulary } \\
\text { sufficient to } \\
\text { express himself } \\
\text { simply with some } \\
\text { circumlocutions }\end{array}$ & $\begin{array}{l}\text { Speaking } \\
\text { vocabulary } \\
\text { inadequate to } \\
\text { express anything } \\
\text { but the most } \\
\text { elementary needs }\end{array}$ \\
\hline Fluency & $\begin{array}{l}\text { Able to use the } \\
\text { language fluently } \\
\text { on all levels } \\
\text { normally } \\
\text { pertinent to } \\
\text { professional } \\
\text { needs. Can } \\
\text { participate in any } \\
\text { conversation } \\
\text { within the range } \\
\text { of this experience } \\
\text { with a high } \\
\text { degree of fluency. }\end{array}$ & $\begin{array}{l}\text { Can discuss } \\
\text { particular } \\
\text { interests of } \\
\text { competence with } \\
\text { reasonable ease. } \\
\text { Rarely has to } \\
\text { grope for words. }\end{array}$ & $\begin{array}{l}\text { Can handle with } \\
\text { confidence but not } \\
\text { with facility most } \\
\text { social situations, } \\
\text { including } \\
\text { introductions and } \\
\text { casual } \\
\text { conversations } \\
\text { about current } \\
\text { events, as well as } \\
\text { work, family, and } \\
\text { autobiographical } \\
\text { information. }\end{array}$ & $\begin{array}{l}\text { No specific fluency } \\
\text { description. Refer } \\
\text { to other four } \\
\text { language areas for } \\
\text { implied level of } \\
\text { fluency. }\end{array}$ \\
\hline Comprehension & $\begin{array}{l}\text { Can understand } \\
\text { any conversation } \\
\text { within the range } \\
\text { of his/her } \\
\text { experience }\end{array}$ & $\begin{array}{l}\text { Comprehension } \\
\text { is quite complete } \\
\text { at a normal rate } \\
\text { of speech }\end{array}$ & $\begin{array}{l}\text { Can get the gist of } \\
\text { most } \\
\text { conversations of } \\
\text { non-technical } \\
\text { subjects (i.e., } \\
\text { topics that require } \\
\text { no specialized } \\
\text { knowledge). }\end{array}$ & $\begin{array}{l}\text { Within the scope of } \\
\text { his very limited } \\
\text { language } \\
\text { experience, can } \\
\text { understand simple } \\
\text { questions and } \\
\text { statements if } \\
\text { delivered with } \\
\text { slowed speech } \\
\text { repetition, or } \\
\text { paraphrase }\end{array}$ \\
\hline $\begin{array}{l}\text { Pronuncia- } \\
\text { tion }\end{array}$ & $\begin{array}{l}\text { Errors in } \\
\text { pronunciation are } \\
\text { quite rare }\end{array}$ & $\begin{array}{l}\text { Errors never } \\
\text { interfere with } \\
\text { understanding } \\
\text { and rarely } \\
\text { disturb the native }\end{array}$ & $\begin{array}{l}\text { Accent is } \\
\text { intelligible though } \\
\text { often quite faulty }\end{array}$ & $\begin{array}{l}\text { Errors in } \\
\text { pronunciation } \\
\text { frequent but can be } \\
\text { understood by a } \\
\text { native speaker used }\end{array}$ \\
\hline
\end{tabular}




\begin{tabular}{|l|l|l|l|l|}
\hline & & $\begin{array}{l}\text { speaker. Accent } \\
\text { may be } \\
\text { obviously } \\
\text { foreign }\end{array}$ & $\begin{array}{l}\text { to dealing with } \\
\text { foreigners } \\
\text { attempting to speak } \\
\text { his language }\end{array}$ \\
\hline Sequencing & $\begin{array}{l}\text { Tells all events } \\
\text { from the story in } \\
\text { the correct order } \\
\text { including story } \\
\text { resolution }\end{array}$ & $\begin{array}{l}\text { Tells major } \\
\text { events form the } \\
\text { beginning, } \\
\text { middle, end }\end{array}$ & $\begin{array}{l}\text { Includes 3-4 } \\
\text { events, may be in } \\
\text { random order }\end{array}$ & $\begin{array}{l}\text { Include } 1 \text { or } 2 \\
\text { events }\end{array}$ \\
\hline
\end{tabular}

\section{RESULTS AND DISCUSSIONS}

This research was conducted in the Kindergarten level at JAC School Surabaya. It consisted of two cycles; there are two meetings for each cycle. The writer did pre-activity before conducted the first cycle to know the situation of the class and the students before used TPRS.

\section{The Pre-activity}

Based on pre-observation above, the writer conducted the pre-activity to see the situation during story telling time. In this pre-activity, the writer asked the teacher to do story telling with story book that teacher usually read for the students. The teacher used story book titled "On the Train" written by Cheryl Rao and published by Cambridge University Press India Pvt. Ltd (2008). The story title is "on the train" based on the transportation theme on that week.

The teacher told story with simple English to explain each events and showed students the picture in the story book. The students are quiet and listen. Also, teacher used funny voice to interest the student. So, from this activity the writer knew the difference between the story telling using story book and using TPRS method. The teacher use English to tell the story

After done with the class activity of telling story titled "On the Train" on the next day, the teacher asked the students skills in retelling the story again about what did they knew from "On the Train" story. Next, the teacher gave the instruction to the students to retelling story, the writer called students one by one and told about the events, the characters, setting of place and time in the story and told it in front of the class. From the pre-activity, the students got the average score 2 said as fair point.

Table 4.3 Student's Score in retelling story "On the Train" the Pre-Activity.

\begin{tabular}{|l|l|l|l|l|l|l|l|l|}
\hline No & Student & Grammar & Vocabulary & Fluency & $\begin{array}{l}\text { Compre- } \\
\text { hension }\end{array}$ & $\begin{array}{l}\text { Pronuncia- } \\
\text { tion }\end{array}$ & Sequencing & Total \\
\hline 1 & S1 & 1 & 2 & 2 & 2 & 3 & 3 & 1 \\
\hline 2 & S2 & 2 & 2 & 2 & 2 & 2 & 2 & 11 \\
\hline 3 & S3 & 3 & 3 & 2 & 2 & 3 & 3 & 11 \\
\hline 4 & S4 & 2 & 2 & 2 & 1 & 2 & 1 & 16 \\
\hline 5 & S5 & 2 & 2 & 2 & 2 & 3 & 2 & 10 \\
\hline 6 & S6 & 2 & 3 & 2 & 3 & 3 & 3 & 13 \\
\hline 7 & S7 & 1 & 2 & 2 & 2 & 2 & 1 & 16 \\
\hline 8 & S & 3 & 2 & 2 & 2 & 4 & 2 & 10 \\
\hline 9 & S9 & 1 & 2 & 2 & 1 & 2 & 1 & 15 \\
\hline 10 & S10 & 1 & 2 & 2 & 1 & 2 & 1 & 9 \\
\hline 11 & S11 & 2 & 2 & 1 & 1 & 2 & 2 & 9 \\
\hline 12 & S12 & 2 & 3 & 2 & 1 & 2 & 2 & 10 \\
\hline 13 & S13 & 2 & 2 & 2 & 2 & 2 & 1 & 12 \\
\hline 14 & S14 & 2 & 1 & 2 & 1 & 2 & 1 & 11 \\
\hline 15 & S15 & 2 & 3 & 2 & 2 & 2 & 2 & 9 \\
\hline 16 & S16 & 2 & 2 & 2 & 1 & 2 & 2 & 13 \\
\hline
\end{tabular}




\begin{tabular}{|l|l|l|l|l|l|l|l|l|}
\hline 17 & S17 & 2 & 3 & 2 & 2 & 2 & 2 & 13 \\
\hline Point average & point 2 & Point 2 & Point 2 & Point 2 & Point 2 & Point 2 & 199 \\
\hline
\end{tabular}

The data above showed students skills in retelling story "on the train" with their own language and their English speaking skills ability. From those data, the writer could make a proper lesson plan by using TPRS method in story telling time. The detailed of the average student results according from the data above, the writer explained it below.

The first it was grammar with most of the students got fair with score 2 points. It means that they generally understand the basic grammar usage such as "Rahul and Meena go by train". It can be accepted as their Kindergarten level. Some of the also said, "Rahul and Meena is happy". It conclude that students just said what they know about the story, without considered the grammar or some of them were just shy to said it in the correct structure because of their first language was not English.

The Vocabulary was also in fair with 2 points. It means, from the pre-activity they had followed, they only mention 5-6 words from the story such as: train, running, inside, sit, down. The teacher mention railway station, luggage, vendor, etc. but no one mentioned it during telling the story. Students needed to memorize the words from the story more as they only knew only few words to tell the story. The students repeat the same word over and over showed that they had difficulty to memorize the other words.

Their fluency was good with the score 3 points. According to this explanation, the students were able to presented English as foreign language to discussed interested topic. It was also indicated that students were easily picked the word they can told the story. It was because they used English as their daily conversation in the class everyday

The comprehension was at fair with 2 points too described that students can get the gist of most conversations of non-technical subjects (i.e., topics that require no specialized knowledge. It means that the student may understand the main discussion of the story but without the detail knowledge of it.

Their pronunciation ability was fair with 2 points that their accent is intelligible though often quite faulty. It indicated that students English accent was forgiven for Young Learners level even often quite made a mistake.

In sequencing, students got fair with 2 points. Most of the student didn't memorize the whole story from the beginning until the end. Moreover, they still retell it randomly. From those data shown, the writer needed to conduct the second cycle and hopes she could make the students score better.

\section{The First Cycle}

Based on pre-observation and pre-activity, the writer knew in story telling time, the teacher only read the English story book to the students every week with different story book each week. The first cycle did on June, $2^{\text {nd }} 2017$. The story title was "over the mountain". The writer was explained the lesson plan to the teacher. Also, we prepared the material of teaching such as the story picture, board marker, etc.

To make sure that the students understand and memorize what the story is about, the writer asked students to retell the story from Over the Mountains with their own language after the teacher using TPRS in the class. The aim of this activity is to gain the information does the vocabulary from the story memorized by students, understand grammar usage based on the teacher statements and repetition, their speaking skill such as fluency, and pronunciation, understand the story by told the story in sequence their comprehension in understand the story.

Table 4.4 Student's Score in retelling story “over the mountains” the first cycle. 


\begin{tabular}{|l|l|l|l|l|l|l|l|l|}
\hline No & Student & Grammar & Vocabulary & Fluency & $\begin{array}{l}\text { Compre- } \\
\text { hension }\end{array}$ & $\begin{array}{l}\text { Pronuncia } \\
\text {-tion }\end{array}$ & $\begin{array}{l}\text { Sequenc- } \\
\text { ing }\end{array}$ & Total \\
\hline 1 & S1 & 1 & 2 & 2 & 2 & 3 & 1 & 11 \\
\hline 2 & S2 & 2 & 2 & 3 & 2 & 2 & 2 & 13 \\
\hline 3 & S3 & 3 & 3 & 2 & 2 & 3 & 3 & 16 \\
\hline 4 & S4 & 2 & 2 & 3 & 1 & 2 & 2 & 12 \\
\hline 5 & S5 & 2 & 2 & 3 & 2 & 3 & 2 & 14 \\
\hline 6 & S6 & 2 & 3 & 2 & 3 & 3 & 3 & 16 \\
\hline 7 & S7 & 1 & 2 & 3 & 2 & 2 & 1 & 11 \\
\hline 8 & S8 & 3 & 2 & 3 & 2 & 4 & 2 & 16 \\
\hline 9 & S9 & 1 & 2 & 3 & 1 & 2 & 1 & 10 \\
\hline 10 & S10 & 2 & 2 & 2 & 1 & 2 & 1 & 10 \\
\hline 11 & S11 & 2 & 2 & 3 & 1 & 2 & 2 & 12 \\
\hline 12 & S12 & 2 & 3 & 3 & 1 & 2 & 2 & 13 \\
\hline 13 & S13 & 2 & 2 & 2 & 2 & 2 & 1 & 11 \\
\hline 14 & S14 & 2 & 1 & 3 & 1 & 2 & 1 & 10 \\
\hline 15 & S15 & 2 & 3 & 3 & 2 & 2 & 2 & 14 \\
\hline 16 & S16 & 2 & 2 & 3 & 1 & 2 & 2 & 12 \\
\hline 17 & S17 & 2 & 3 & 2 & 2 & 2 & 2 & 13 \\
\hline Point average & point 2 & Point 2 & Point 3 & Point 2 & Point 2 & Point 2 & 214 \\
\hline
\end{tabular}

The result above showed that most of students still need practice to retell the story with their own language. The writer also needed to encourage the teacher to presenting the TPRS method so it could be understood by all students. Students need practice to use grammar. The writer has counted the mean of the data and the results are shown above.

In grammar most of the students got fair with score 2 points. This point indicated that they generally understand the grammar usage but they need to use the grammar carefully and encouragement to be more confident. Some of them said "he go to Jakarta, with the train, he go to grandma's house with the ship".

The Vocabulary is also in fair with 2 points. It means, after the student followed TPRS lesson in the first cycle, they still needed to memorize the words from the story more as they only knew only few words to tell the story. Some of them mentioned 7-8 vocabularies from the story such as car, ship, train, riding, horse, grandma's house, mountain, Sea. Even their average score still the same with pre-activity, the students able to mentioned more vocabulary around 7-8 words. It was because the teacher did repetition of each new word and explained the meaning. The fluency indicated as good with the score 3 points. The students were able to presented English as foreign language to discussed interested topic. It was also indicated that students were easily picked the word they can told the story. It was because they used English as their daily conversation in the class. Also, it indicated that they were listening and understanding the story quite well. The story they told was makes sense and easily to understand.

The comprehension was at fair with 2 points too described that students can get the gist of most conversations of non-technical subjects (i.e., topics that require no specialized knowledge. It means that the student may understand the main discussion of the story but they both described the story in detail.

Their pronunciation ability was fair with 2 points that their accent is intelligible though often quite faulty. The teacher had asked students to repeated what teacher said over and over again during TPRS process so, students were mentioned it better and clear enough. However, they still made a mistake such as "grandma house".

In sequencing, students got fair with 2 points indicated that they includes 3-4 events, may be in random order. Most of the student didn't memorize the whole story from the beginning until the end. 
Moreover, they still retell it randomly. From those data shown, the writer needed to conduct the second cycle and hopes she could make the students score better.

Even the first cycle not boosted an improvement in student story retelling, but there were differences between the total of both pre-activity and the first cycle. The pre-activity total students score was 199 and the first cycle total was 215 . With the different 16 points however, the first cycle did an improvement in student retelling a little better than the story telling time in pre-activity.

\section{The Second Cycle}

The writer did the second cycle on June, $6^{\text {th }} 2017$ after reflecting the process in the first cycle. In the first cycle writer has checked the teacher and students checklist and wrote field note during process of using TPRS. The writer conducted the second cycle to study over again the TPRS implementation with the teacher that in the first cycle missed some steps and activities such as:

a. The teacher needs to use gesture during telling the story.

b. The teacher needs to show the pictures to the students clearly.

c. The teacher missed the TPRS step: asking personal question to the students.

d. The teacher didn't taught life lesson after taught students the story

e. Also improved the student ability in retelling story needed to improve.

As we seen above, the first cycle missed some TPRS activities. The writer prepared the second story and the title was "I'm too ill". From the rubric of retelling story in first cycle, the average of the students got only 2 points in grammar, vocabulary, fluency, comprehension, pronunciation and sequencing. In the second cycle, the writer tries to make an improvement of it by made the new lesson plan of second cycle. The result of students' skills in the first cycle retelling story explained below.

Table 4.5 Student's Score in retelling story "I'm too Ill" the second cycle.

\begin{tabular}{|l|l|l|l|l|l|l|l|l|}
\hline No & Name & Grammar & Vocabulary & Fluency & $\begin{array}{l}\text { Compre- } \\
\text { hension }\end{array}$ & $\begin{array}{l}\text { Pronuncia- } \\
\text { tion }\end{array}$ & $\begin{array}{l}\text { Sequenc- } \\
\text { ing }\end{array}$ & Total \\
\hline 1 & S1 & 3 & 3 & 4 & 3 & 3 & 3 & 19 \\
\hline 2 & S2 & 3 & 4 & 4 & 3 & 4 & 4 & 22 \\
\hline 3 & S3 & 4 & 4 & 3 & 3 & 4 & 4 & 22 \\
\hline 4 & S4 & 4 & 3 & 4 & 3 & 4 & 4 & 22 \\
\hline 5 & S5 & 4 & 4 & 3 & 3 & 4 & 4 & 22 \\
\hline 6 & S6 & 4 & 4 & 3 & 4 & 4 & 3 & 22 \\
\hline 7 & S7 & 3 & 4 & 4 & 3 & 3 & 4 & 21 \\
\hline 8 & S8 & 4 & 4 & 4 & 3 & 4 & 4 & 23 \\
\hline 9 & S9 & 3 & 3 & 4 & 3 & 4 & 3 & 20 \\
\hline 10 & S10 & 3 & 3 & 4 & 3 & 3 & 3 & 19 \\
\hline 11 & S11 & 3 & 4 & 3 & 3 & 4 & 4 & 21 \\
\hline 12 & S12 & 3 & 4 & 3 & 3 & 3 & 4 & 20 \\
\hline 13 & S13 & 3 & 4 & 3 & 3 & 4 & 4 & 21 \\
\hline 14 & S14 & 3 & 4 & 4 & 3 & 4 & 4 & 22 \\
\hline 15 & S15 & 4 & 4 & 3 & 4 & 3 & 4 & 22 \\
\hline 16 & S16 & 3 & 3 & 4 & 3 & 4 & 4 & 21 \\
\hline 17 & S17 & 3 & 4 & 3 & 3 & 4 & 3 & 20 \\
\hline Point Average & 3 & 4 & 3 & 3 & 4 & 4 & 419 \\
\hline
\end{tabular}

The result of students skills in retelling story in the second cycle shows above showed that the students retelling story boosted using TPRS method with the story "I'm too Ill". There was significant 
improvement in students' vocabulary, pronunciation and story sequence. In this second cycle, the teacher tells the story very well and completely interests the student. Most of students telling the story in rote and explained the events based on the story.

The grammar of student achievement got good marked with the average score 3 . Students were able to speak the language with sufficient structural accuracy to participate effectively in most formal and informal conversations on practical, social, and professional topics. It made improvement from the first cycle that was in point 2. The student had a good control in grammar and spoke the statements accurately with their good confident. In retelling, they mentioned the statements such as "Siriwat had a sore throat, his dad asked him to drink medicine".

Next, the student vocabulary got very high score with 4 points means excellent. It made an admirable improvement in promoted student's vocabulary. The indication of excellent score that student could understand and participate in any conversation within the range of his experience with a high degree of precision. In this level, students understand the most vocabulary what the story told about. 13 students out of 17 mentioned the main vocabulary about illness such as sore throat, head ache, tummy ache, earache, medicine, too ill and many more.

The fluency of the students stays in 3 points with good score indicated that students can discuss particular interests of competence with reasonable ease. Rarely has to grope for words. There was no improvement of fluency level in second cycle. It was because not all students had a readiness of speech especially for those who were only used English only at school.

The comprehension score was good with 3 points. This skill improved from the first cycle that only 2 points. It said student comprehension is quite complete at a normal rate of speech. It means that student. The students were understood about the story fully. They know what happened to the character, the idea, the causal of what happened to the character, etc. by using TPRS method.

The students also made a great improvement in pronunciation with 4 points described as excellent that the students Errors in pronunciation are quite rare. It was much better that the score they got in the first cycle. In this second cycle, the teacher asked students to repeat the words and sentence many times to made them able to say it. With excellent score of pronunciation, the writer almost caught up students said every word correctly even the word "sore throat"

Sequencing as the last assessment was important to indicate does the students listening and understanding the story from the beginning until the end. In this part of scoring, student reached excellent score with 4 points where the students Tells all events from the story in the correct order including story resolution. The story was easy to understand by the student. Also, it was only focused on the illness of the character named Siriwat. The students told the situation of siriwat in the beginning of the story until the end of it in a correct order.

From the result of the data above, the writer and the teacher felt satisfied to the students' skill of retelling story was improved. The teacher did the TPRS process well and made the students understood the story easily. From the reflection of the first cycle the writer planned a lesson activity with a very simple and easy understandable story for Young Learners student.

\section{Discussions}

From the data that have been analyzed in the finding, the writer concluded implementation of using TPRS method in teaching English for young learners. From that activity, the writer measured the student ability in retelling story. Especially in the second cycle which students got the highest score as excellent 
point. There was comparison between story telling in the class and Using TPRS. The comparison before and after TPRS method explained below:

\begin{tabular}{|l|l|l|}
\hline No. & \multicolumn{1}{|c|}{ Before Using TPRS } & \multicolumn{1}{c|}{ After Using TPRS } \\
\hline 1 & The lesson plan was only about the story & $\begin{array}{l}\text { The lesson plan contained the story, } \\
\text { teacher's question and worksheet }\end{array}$ \\
\hline 2 & $\begin{array}{l}\text { The students didn't respond teacher's } \\
\text { question about the story }\end{array}$ & $\begin{array}{l}\text { The students responded teacher's question } \\
\text { about the story }\end{array}$ \\
\hline 3 & Students couldn't retell the story & $\begin{array}{l}\text { Students were able to retell the story with } \\
\text { their own language about the story }\end{array}$ \\
\hline 4 & $\begin{array}{l}\text { There was no worksheet after story telling } \\
\text { time }\end{array}$ & $\begin{array}{l}\text { There was worksheet for students after } \\
\text { story telling time }\end{array}$ \\
\hline 5 & Teacher didn't translated the story & $\begin{array}{l}\text { Teacher translated the story in TPRS step } \\
\text { i: Establish Meaning }\end{array}$ \\
\hline 6 & $\begin{array}{l}\text { Teacher didn't asked students to read the } \\
\text { words/sentences in the story }\end{array}$ & $\begin{array}{l}\text { Teacher asked students to repeat to read } \\
\text { the words/sentences in the story after the } \\
\text { teacher }\end{array}$ \\
\hline
\end{tabular}

On the pre-activity, the teacher told a story with story book titled On the Train. The teacher asked students to listen to the story carefully and asked them to keep quiet. The objective of this meeting was to observed teacher and students activities during story telling time. The students of K1A class looked enjoyed the story. It can be seen from their expression and their faces looked curious of what happened in the story next. The writer asked students to retelling On the Train story with their own language to know K1A student ability in retelling story using English in the post activity. Based on the data, the score average of students retelling got 2 from 4 points. It indicated that the students need to practice to retelling story.

The first cycle using TPRS method in teaching English, the writer gave the lesson plan and prepared the material together before did the activity in first cycle. The story contained vocabulary of transportation. The students was enthusiastic followed the activity of using TPRS. It proved from their involvement during the activity by answered teacher question and their excitement for being the actor. Even the teacher missed some activity that should be done in using TPRS method in teaching English, he did it well as it his first time as it was the first time taught this new method. The post activity showed that students score didn't made any improvement from the pre-activity post-activity of retelling story.

The second cycle was done after the writer analyzed the observation in the first cycle. On the second, the writer did the same preparation as the first cycle. After the writer and the teacher talked together what activity of TPRS what need should be done or need an improvement. The second cycle story of Using TPRS told about a boy who had illness. The story was easier to understand by students. In the second cycle, the teacher had done all the activities and the steps of TPRS well. The students were excited with the story. After did the second cycle activity, the writer did the post activity on the next day. The post activity showed that students score made an improvement from the first cycle to the second cycle of retelling story.

The second question is about how is the improvement of Young Learners students in retelling the story. The result of the data in the second cycle answered question problem number two, the students' ability in retelling story made an improvement from the first to the second cycle. With the total score of the first cycle was 214 and 419 on the second cycle. The average of students score was 2 in the first cycle and 4 in the 
second cycle. The writer and the teacher felt satisfied to the students that made an improvement in retelling story. The teacher did the TPRS process well and made the students understood the story easily so they finally could retelling the story with their own language in the best way.

\section{CONCLUSION}

Based on the result of data analysis the writer concluded that the implementation of Teaching Proficiency through Reading and Storytelling (TPRS) method was done in two cycles. The student had actively answer teacher's question and being actor enthusiastically. It improved students' ability in retelling story.

The improvement of students' achievement in retelling story after being taught by using TPRS method can be seen from the average score of students in the first and second cycle. The average of students score was 2 in the first cycle and 4 in the second cycle. The students made a great improvement on vocabulary, pronunciation and story sequence to reach the highest score. It means that TPRS suitable to teach English for Young Learners.

\section{REFERENCES}

Brown, H. Douglas. 2003. Language Assessment Principles and Classroom Practices. $\quad$ California: Longman

Burns, Anne. 2010. Doing Action Research In English Language Teaching: New York: Routledge

Cameron, Lynn. 2001. Teaching Languages to Young Learners. United Kingdom: Cambridge

University Press.

Ellis, Gail and Jean Brewster, 2014. Tell it Again! The Storytelling Handbook for Primary English Language Teachers. British Council

Hedstrom, Bryce. 2012. The Basic of TPRS. Workshop Notes and Pre-Reading.

Linse, Caroline T and David Nunan. 2005. Practical English Language Teaching: $\quad$ Young $\quad$ Learners. New York: McGraw-Hill Companies.

Ray, Blaine and Contee Seely. 2012. Fluency Through TPR Storytelling Achieving Real Language Acquisition in School. USA: Blaine Ray Workshops and Command Performance Language Institute

Ray, Blaine. 2011. Teaching Proficiency through Reading and Storytelling. USA: Blaine Ray Workshop, Inc. 